\title{
Diastereoselective One-Pot Synthesis of Succinimides Bearing a Chromone Unit
}

\author{
Mohammad Bagher Teimouri*a \\ Bita Asnaasharia \\ Maryam Moayedib \\ Soheila Naderic \\ a Faculty of Chemistry, Kharazmi University, Mofateh Ave., Tehran, \\ Iran \\ teimouri@khu.ac.ir \\ b Faculty of Chemistry, Omidiyeh Branch, Islamic Azad University, \\ Omidiyeh, Iran \\ ' Faculty of Chemistry, Shahid Beheshti University, PO Box 19396- \\ 4716, Tehran, Iran
}

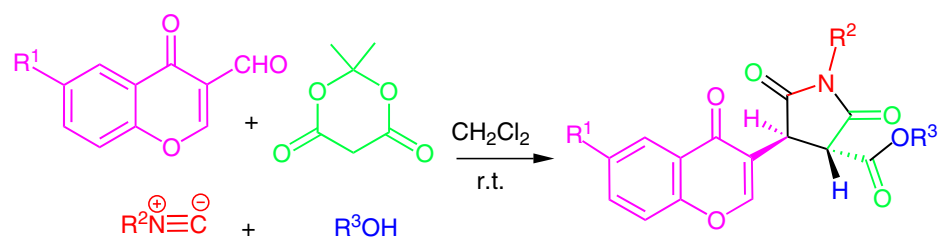

Succinimide-substructure-containing compounds show Accepted after revision: 12.10.2014

Published online: 11.11 .2014

DOI: 10.1055/s-0034-1378926; Art ID: st-2014-d0688-

Abstract A diastereoselective synthesis of highly substituted succinimide derivatives with chromone and carboxylic ester functionalities from 3-formylchromones, Meldrum's acid, and alkyl isocyanides in the presence of alcohols in moderate to good yields is described.

Key words formylchromone, isocyanide, Meldrum's acid, succinimide

Succinimides represent a privileged scaffold in medicinal chemistry, and this structural motif can be found in many natural products such as moiramide $B$, andrimid, hirsutellone A, and haterumaimide A (Figure 1 ). ${ }^{1}$<smiles>C/C=C/C=C/C(=O)NC(CC(=O)N[C@H](C(=O)[C@@H]1C(=O)NC(=O)[C@H]1C)C(C)C)c1ccccc1</smiles>

moiramide $B(n=1)$ andrimide $(\mathrm{n}=2)$<smiles>C=C1C(OC(C)=O)C[C@H]2C(C)(C)C[C@@H](Cl)C[C@]2(C)C1CC(O)[C@H]1CC(=O)NC1=O</smiles>

haterumaimide $\mathrm{A}$

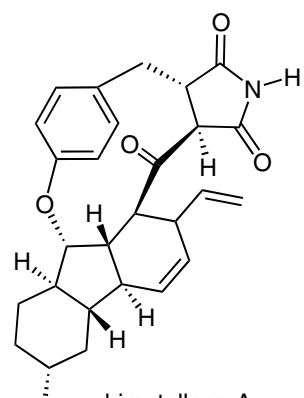

$\vdots$ hirsutollene A
Figure 1 Examples of biologically active succinimide-containing natural products great pharmacological potential acting as enzyme inhibitors, analgesics, antimicrobial agents, anxiolytics, cytotoxic, anticonvulsants, antitumor drugs, and anti-Parkinson's agents. $^{2}$ On the other hand, chromones are an important moiety, forming the nucleus of a class of heterocyclic natural products called flavanoids that occur naturally in fruits, vegetables, nuts, seeds, flowers, and bark. ${ }^{3}$ They are an integral part of the human diet and have been reported to exhibit a wide range of biological effects. ${ }^{4}$ They display not only spasmolytic, diuretic, clotting, antibacterial, antiviral, antitumoral, anti-inflammatory, and anti-anaphylactic activity, but can also be used as antioxidants, pigments, photoactive materials, and biodegradable agrochemicals. ${ }^{5}$

Meldrum's acid and its 5-arylidene or 5-alkylidene derivatives (which are readily accessible from the reactions of Meldrum's acid and aldehydes or ketones) have acquired considerable interest as highly reactive electron-deficient heterodienes in isocyanide-based multicomponent reacrelatively facile routes to amidodiesters and triamides by taking advantage of Meldrum's acid derivatives. These compounds were obtained by treatment of Meldrum's acids with aldehydes (5-alkylidene or 5-arylmethylidene Meldrum's acids) and isocyanides in the presence of such nucleophiles as alcohols, ${ }^{6 \mathrm{a}-\mathrm{c}}$ phenols, ${ }^{6 \mathrm{c}}$ and primary amines $^{6 \mathrm{~d}}$ in dichloromethane. Based on these efficient and useful multicomponent reactions, more efforts were made to investigate the reactions of Meldrum's acid derivatives and isocyanides with other nucleophiles such as water, ${ }^{7} \mathrm{di}-$ ols, ${ }^{8}$ arylhydroxylamines, ${ }^{9}$ aryl hydrazines, ${ }^{10}$ 2-hydroxy benzaldehydes, ${ }^{11}$ sugar hydroxyaldehydes, ${ }^{12}$ and urea, ${ }^{13}$ which produced 4-oxobutanoic acids, 2-arylisoxazolidine3,5-diones, 1,4-dioxepane-5,7-diones, 1-arylpyrazolidine3,5-diones, 3,4-dihydrocoumarins, 5-oxo-perhydrofuro[3,2-b]pyrans, and barbituric acid derivatives, respectively. tions. In our earlier publications, ${ }^{6}$ we have described four 
Recently, we reported the pseudo-five-component tandem reaction of 3-formylchromones, Meldrum's acid, and isocyanides with primary aryl amines, which offers an efficient route to construct chromone-containing tripeptides under mild conditions with high efficiency. ${ }^{14}$ However, when the substrate combination was switched from primary aryl amines to alcohols, to our surprise, none of the expected products $\mathbf{5}$ were obtained. We now disclose a new multicomponent cascade reaction of 3-formylchromones $\mathbf{1}$ with Meldrum's acid (2), isocyanides 3, and alcohols 4 diastereoselectively providing polyfunctionalized succinimide derivatives 6 (Scheme 1).<smiles>O=c1c(Cl)coc2ccc(Br)cc12</smiles>
$\mathrm{CH}_{2} \mathrm{Cl}_{2}$ r.t.

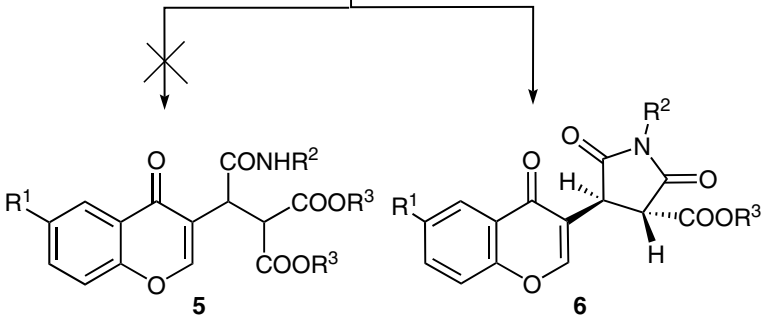

Scheme 1 Synthesis of chromone-bound succinimides 6 for the two methine $\left(\delta_{\mathrm{H}}=4.02\right.$ and $\left.4.08 \mathrm{ppm},{ }^{3} J_{\mathrm{HH}}=6.1 \mathrm{~Hz}\right)$ protons of the succinimide moiety and methylene protons $\left(\delta_{\mathrm{H}}=4.75\right.$ and $\left.4.86 \mathrm{ppm},{ }^{2} J_{\mathrm{HH}}=14.4 \mathrm{~Hz}\right)$. The aromatic protons gave rise to multiplets and a doublet in the aromatic region of the spectrum $\left(\delta_{\mathrm{H}}=7.26-7.94\right.$ and $\delta_{\mathrm{H}}=7.95 \mathrm{ppm}$, ${ }^{3} J_{\mathrm{HH}}=5.9 \mathrm{~Hz}$ ). The vinylic methine occurred as a sharp singlet $\left(\delta_{\mathrm{H}}=7.96 \mathrm{ppm}\right)$.

The ${ }^{1} \mathrm{H}$-decoupled ${ }^{13} \mathrm{C}$ NMR spectrum of $\mathbf{6 i}$ showed 30 distinct resonances in agreement with the suggested structure.

Encouraged by the results obtained with the above reaction conditions, and in order to show the generality and scope of this new protocol, we turned our attention to various 3-formylchromones, isocyanides, and alcohols. Four 3formylchromones, six alkyl or aryl isocyanides, and eleven alcohols were examined. Two 3-formylchromone derivatives (3-formylchromone and 3-formyl-6-methyl-chromone) afforded chromone-bound succinimides in moderate to good yields. Furthermore, it was observed that the nature of the substituents at C- 6 and C- 8 of the chromone ring affects the reaction significantly. Under similar reaction conditions, starting with Meldrum's acid, cyclohexyl isocyanide, ethanol, and chlorinated 3-formylchromones, such as 6-chloro-3-formylchromone or 6,8-dichloro-3-formylchromone, the corresponding known products ${ }^{16}(1 Z)-7$-chloro1-[(6-chloro-4-oxo-4H-chromen-3-yl)methylene]-3-(cyclohexylimino)-1,3-dihydro-9H-furo[3,4-b]-chromen-9one (7a) and (1Z)-5,7-dichloro-3-(cyclohexylimino)-1-[(6,8dichloro-4-oxo-4H-chromen-3-yl)methylene]-1,3-dihydro9H-furo[3,4-b]chromen-9-one (7b) were isolated, respectively, without the participation of Meldrum's acid and ethanol, which did not enter into these reactions.

In addition, found that the reactions proceeded very efficiently with alkyl isocyanides (cyclohexyl isocyanide, benzyl isocyanide, 1,1,3,3-tetramethylbutyl isocyanide, and 2-morpholinoethyl isocyanide), but failed to furnish the expected chromone-bound succinimide derivatives with aryl isocyanides (2,6-dimethylphenyl isocyanide and 2-naphthyl isocyanide).

A variety of structurally diverse alcohols underwent the one-pot reaction smoothly without need for a catalyst to afford the corresponding succinimide derivatives in good yields. As shown in Table 1, primary alcohols (ethanol, 1propanol, 1-butanol, and 1-pentanol) benzylic alcohols (benzyl- and 4-chlorobenzyl alcohol), heterocyclic alcohol (2-furylmethanol), hindered and unhindered secondary and tertiary alcohols (2-adamantol, cyclohexanol, and tertamyl alcohol) were used in this protocol with good results.

In the case of the sterically unhindered methanol, the amido diester fragments were formed instead of the expected formation of succinimide moieties (Table 1, entries 12 and 13). 
Synlett

M. B. Teimouri et al.

Letter

Table 1 Structure of Compounds $\mathbf{6 a - k}$ and $\mathbf{5 a - b}$

Entry 3-Formylchromone Alcohol

Isocyanide

Product

Yield (\%)<smiles>Cc1ccc2occ(C=O)c(=O)c2c1</smiles>

$\mathrm{EtOH}$<smiles>Cc1ccc2occ(C=O)c(=O)c2c1</smiles><smiles>CCCO</smiles>

3<smiles>Cc1ccc2occ(C=O)c(=O)c2c1</smiles><smiles>CCCCO</smiles><smiles>[N+]=[N+]1CCCCC1</smiles><smiles>[N-][C]1CCCCC1</smiles><smiles>N#CCc1ccccc1</smiles><smiles>Cc1ccc2occ(C=O)c(=O)c2c1</smiles><smiles>CCCCCO</smiles><smiles>OCc1ccccc1</smiles><smiles>O=Cc1coc2ccccc2c1=O</smiles>

5

6<smiles>Cc1ccc2occ(C=O)c(=O)c2c1</smiles><smiles>OCc1ccc(Cl)cc1</smiles>

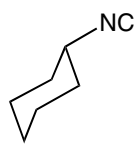<smiles>CCCC(CCC)N1C(=O)C(C(=O)OCC)C(c2coc3ccc(C)cc3c2=O)C1=O</smiles>

$6 a$<smiles>CCCOC(=O)[C@H]1C(=O)N(C2CCCCC2)C(=O)[C@H]1c1coc2ccc(C)cc2c1=O</smiles>

6b<smiles>CCCCOC(=O)[C@H]1C(=O)N(C2CCCCC2)C(=O)[C@H]1c1coc2ccc(C)cc2c1=O</smiles>

$6 c$<smiles>CCCCCOC(=O)[C@H]1C(=O)N(Cc2ccccc2)C(=O)[C@H]1c1coc2ccc(C)cc2c1=O</smiles><smiles>O=C(OCc1ccccc1)[C@H]1C(=O)N(C2CCCCC2)C(=O)[C@@H]1c1coc2ccccc2c1=O</smiles>

60

$6 e$

60

70

6f
65

67

69 
7<smiles>O=Cc1coc2ccccc2c1=O</smiles><smiles>OCc1ccco1</smiles><smiles>OC1CCCCC1</smiles><smiles>OC1C2CC3CC(C2)CC1C3</smiles><smiles>Cc1ccc2occ(C=O)c(=O)c2c1</smiles><smiles>O=Cc1coc2ccccc2c1=O</smiles><smiles>OC1C2CC3CC(C2)CC1C3</smiles><smiles></smiles><smiles>[N-]Cc1ccccc1</smiles><smiles>[N-]=[N+]=[N-]</smiles>

6h<smiles>O=C(OCc1ccco1)[C@H]1C(=O)N(C2CCCC2)C(=O)[C@H]1c1coc2ccccc2c1=O</smiles>

$6 g$<smiles>Cc1ccc2occ([C@H]3C(=O)N(C4CCCC4)C(=O)[C@H]3C(=O)OC3CCCCC3)c(=O)c2c1</smiles><smiles>Cc1ccc2occ([C@H]3C(=O)N(Cc4ccccc4)C(=O)[C@H]3C(=O)OC3C4CC5CC(C4)CC3C5)c(=O)c2c1</smiles><smiles>O=C(OC1C2CC3CC(C2)CC1C3)[C@H]1C(=O)N(CCN2CCOCC2)C(=O)[C@H]1c1coc2ccccc2c1=O</smiles>

6j<smiles>CCC(C)(C)OC(=O)[C@H]1C(=O)N(C2CCCCC2)C(=O)[C@H]1c1coc2ccc(C)cc2c1=O</smiles>

$6 k$<smiles>COC(=O)C(C(=O)OC)C(C(=O)NC(C)(C)CC(C)(C)C)c1coc2ccc(C)cc2c1=O</smiles><smiles>COC(=O)C(C(=O)OC)C(C(=O)NC1CCCCC1)c1coc2ccc(C)cc2c1=O</smiles>

62

55

50
13<smiles>Cc1ccc2occ(C=O)c(=O)c2c1</smiles>

$\mathrm{MeOH}$

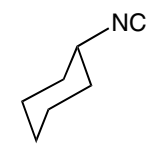

a Yield of pure isolated product. 
A plausible mechanism for the formation of the fully functionalized succinimides $\mathbf{6}$ is proposed in Scheme 2. The reaction may be rationalized by initial formation of the conjugated electron-deficient heterodiene by Knoevenagel condensation of the 3-formylchromone $\mathbf{1}$ and Meldrum's acid (2), followed by a [4+1]-cycloaddition reaction with isocyanide $\mathbf{3}$ to afford an iminolactone intermediate $\mathbf{9}$. Conjugate addition of the alcohol on the enone moiety of $\mathbf{9}$, followed by cleavage of the five-membered iminolactone ring gives $\mathbf{1 0}$ and hence the $\alpha$-oxoketene $\mathbf{1 1}$ by well precedented ${ }^{17}$ electrocyclic ring opening of O-alkylated Meldrum's acids. The $\alpha$-oxoketene $\mathbf{1 1}$ can then undergo intramolecular reaction between the amide and ketene moieties to give stable carbanion intermediate $\mathbf{1 2}$. The resulting enolate $\mathbf{1 2}$ undergoes stereoselective reprotonation to yield the thermody- namically favorable isomer of the product $\mathbf{6}$. Among the alcohols studied, only methanol, as the least sterically hindered alcohol, can compete with the adjacent amide nitrogen atom in attacking the ketene moiety to produce the dimethyl malonate derivative $\mathbf{5}$.

It is important to note that compound $\mathbf{6}$ has two stereogenic centers, and therefore, two pairs of diastereoisomers are expected. The ${ }^{1} \mathrm{H}$ NMR and ${ }^{13} \mathrm{C}$ NMR spectra of the crude reaction mixture obtained from products were consistent with the presence of only one diastereomer. All measured coupling constants for the protons $\mathrm{H} 3$ and $\mathrm{H} 4$ in compounds $\mathbf{6 a}-\mathbf{k}$ are in the range of $6.0-6.8 \mathrm{~Hz}$ which suggests a trans arrangement for these two hydrogen atoms. The relative configuration was determined by X-ray crystalstructure analysis in the case of $\mathbf{6 i}$ (Figure 2).<smiles>O=Cc1coc2ccc([Tl])cc2c1=O</smiles>

1<smiles>CC1(C)OC(=O)CC(=O)O1</smiles><smiles>[R]C1(C)OC(=O)C(=Cc2coc3ccc([Tl])cc3c2=O)C(=O)O1</smiles>

8<smiles></smiles><smiles>[R7]N=C1OC2=C(C(=O)OC(C)(C)O2)C1c1coc2ccc([R])cc2c1=O</smiles><smiles>[R7]NC(=O)C(C(=O)OC)C(C(=O)OC)c1coc2ccc([Tl])cc2c1=O</smiles>

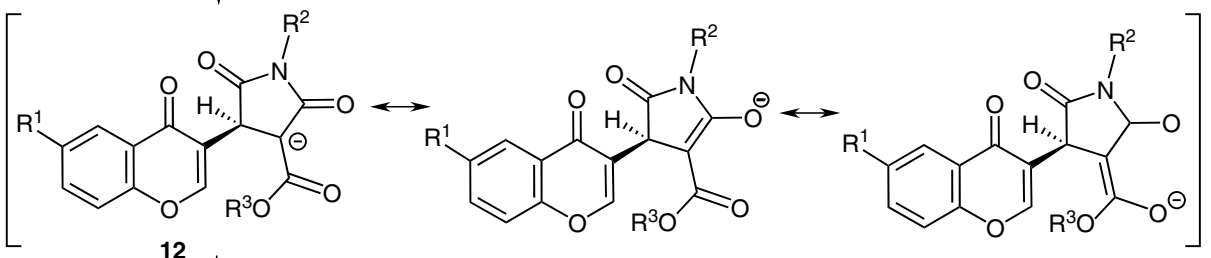<smiles>[R]N1C(=O)[C@@H](C(=O)O)[C@@H](c2coc3ccc([Tl])cc3c2=O)C1=O</smiles>

Scheme 2 Possible mechanisms for the formation of products 5 and $\mathbf{6}$ 


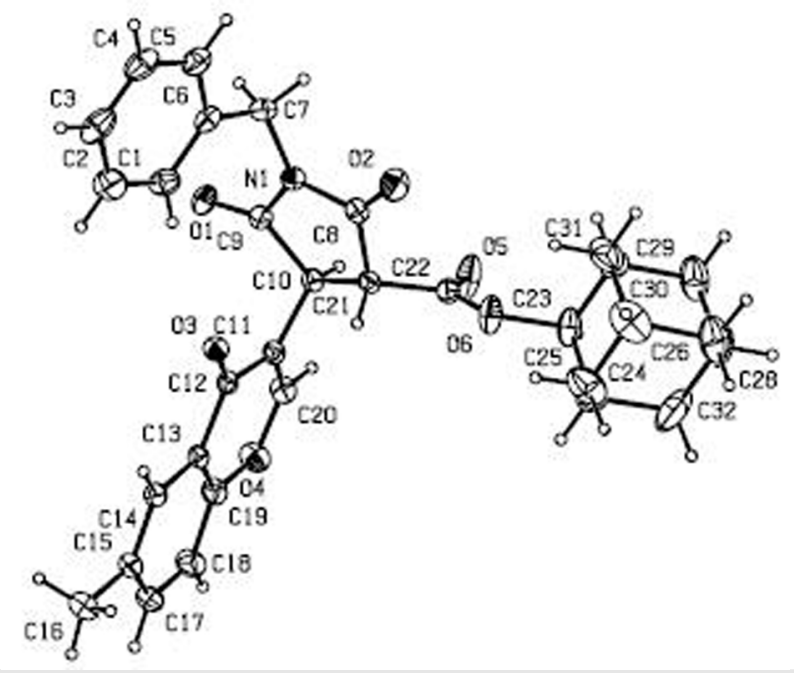

Figure 2 X-ray crystal structure of $(3 R, 4 S)-6 \mathbf{i}$

In summary, we have developed a four-component tandem reaction for the formation of biologically interesting chromone-bound succinimides. The merit of this diastereoselective cascade reaction is highlighted by its mild reaction conditions, easy workup, acceptable yields, high bond efficiency of producing five new bonds (two $\mathrm{C}-\mathrm{C}$ and three $\mathrm{C}-$ heteroatom), and two stereocenters in a single operation.

\section{Acknowledgment}

The authors thank Kharazmi University Research Council for financial support of this research.

\section{Supporting Information}

Supporting information for this article is available online at http://dx.doi.org/10.1055/s-0034-1378926.

\section{References and Notes}

(1) Lin, G.-J.; Luo, S.-P.; Zheng, X.; Ye, J.-L.; Huang, P.-Q. Tetrahedron Lett. 2008, 49, 4007.

(2) Banjac, N.; Trišović, N.; Valentic, N.; Ušćumlic, G.; Petrović, S. Hem. Ind. 2011, 65, 439.

(3) Malikov, V. M.; Yuldashev, M. P. Chem. Nat. Compd. 2002, 38, 358.

(4) Chan-Bacab, M. J.; Peña-Rodríguez, L. M. Nat. Prod. Rep. 2001, $18,674$.

(5) Ellis, G. P.; Lockhart, I. M. The Chemistry of Heterocyclic Compounds, Chromenes, Chromanones, and Chromones; Vol. 31; Ellis, G. P., Ed.; Wiley-VCH: Weinheim, 2007.

(6) (a) Shaabani, A.; Yavari, I.; Teimouri, M. B.; Bazgir, A.; Bijanzadeh, H. R. Tetrahedron 2001, 57, 1375. (b) Shaabani, A.; Teimouri, M. B.; Bijanzadeh, H. R. Russ. J. Org. Chem. 2004, 40,
976. (c) Shaabani, A.; Teimouri, M. B.; Bazgir, A.; Bijanzadeh, H. R. Mol. Diversity 2003, 6, 199. (d) Teimouri, M. B.; Akbari-Moghaddam, P. Tetrahedron 2011, 67, 5928.

(7) Shaabani, A.; Teimouri, M. B. J. Chem. Res., Synop. 2003, 433.

(8) Yavari, I.; Sabbaghan, M.; Hossaini, Z. Mol. Diversity 2007, 11, 1.

(9) Habibi, A.; Mousavifar, L.; Yavari, I.; Yazdanbakhsh, M. R. Monatsh. Chem. 2007, 138, 603.

(10) Yavari, I.; Sabbaghan, M.; Ghazanfarpour-Darjani, M.; Hossaini, Z. J. Chem. Res. 2007, 392.

(11) (a) Shaabani, A.; Soleimani, E.; Rezayan, A. H.; Sarvary, A.; Khavasi, H. R. Org. Lett. 2008, 10, 2581. (b) Shaabani, A.; Sarvary, A.; Soleimani, E.; Rezayan, A. H.; Heidary, M. Mol. Diversity 2008, 12, 197.

(12) Subba Reddy, B. V.; Nilanjan Majumder, N.; Hara Gopal, A. V.; Chatterjee, D.; Kunwar, A. C. Tetrahedron Lett. 2010, 51, 6835.

(13) Habibi, A.; Tarameshloo, Z. J. Iran. Chem. Soc. 2011, 8, 287.

(14) Teimouri, M. B.; Akbari-Moghaddam, P.; Golbaghi, G. ACS Comb. Sci. 2011, 13, 659.

(15) General Procedure for the Synthesis of Alkyl-1-alkyl-4-(4oxo-4H-chromen-3-yl)-2,5-dioxopyrrolidine-3-carboxylates 6

A mixture of the appropriate 3-formylchromone 1 (1 mmol) and Meldrum's acid $(2,1 \mathrm{mmol})$ was stirred in anhydrous $\mathrm{CH}_{2} \mathrm{Cl}_{2}(10 \mathrm{~mL})$ for $3 \mathrm{~h}$ at r.t., and then alcohol 4 (1 mmol) followed by alkyl isocyanide 3 ( $1 \mathrm{mmol}$ ) was added at r.t. After complete conversion, as monitored by TLC using EtOAc-hexane $(1: 1)$ as eluent, the mixture was concentrated in vacuo, and the solid residue was washed with $\mathrm{Et}_{2} \mathrm{O}$ and crystallized from $\mathrm{CH}_{2} \mathrm{Cl}_{2}$-hexane (1:3) to afford pure product 6 .

rac-2-Adamantyl (3R,4S)-1-Benzyl-4-(6-methyl-4-oxo-4Hchromen-3-yl)-2,5-dioxopyrrolidine-3-carboxylate (6i)

White powder; mp $195-196{ }^{\circ} \mathrm{C}$ (melt.). IR (KBr): $v_{\max }=1783$, 1709, 1646 (C=0), 1616 (C=C) cm ${ }^{-1} .{ }^{1} \mathrm{H}$ NMR (300.1 MHz, $\mathrm{CDCl}_{3}$ ): $\delta=1.49-2.06(14 \mathrm{H}, \mathrm{m}$, adamantyl $), 2.45\left(3 \mathrm{H}, \mathrm{s}, \mathrm{CH}_{3}\right), 4.02$ and $4.08\left(2 \mathrm{H}, \mathrm{AB}-q\right.$ system, $\left.{ }^{3} J_{\mathrm{HH}}=6.1 \mathrm{~Hz}, \mathrm{CHCH}\right), 4.75$ and $4.86(2 \mathrm{H}$, AB- $q$ system, $\left.{ }^{2} J_{\mathrm{HH}}=14.4 \mathrm{~Hz}, \mathrm{PhCH}_{2}\right), 5.00(1 \mathrm{H}, \mathrm{m}, \mathrm{OCH}), 7.26-$ $7.94\left(7 \mathrm{H}, \mathrm{m}\right.$, arom. H), $7.95\left(1 \mathrm{H}, \mathrm{d},{ }^{3} \mathrm{H}_{\mathrm{HH}}=5.9 \mathrm{~Hz}\right.$, arom. H.), 7.96 $(1 \mathrm{H}, \mathrm{s}, \mathrm{C}=\mathrm{CHO}) .{ }^{13} \mathrm{C}$ NMR $\left(75.5 \mathrm{MHz}, \mathrm{CDCl}_{3}\right): \delta=176.6,174.9$, $170.8,166.8,154.8,154.6,135.8,135.6,135.3,128.6,128.2$, 127.8, 125.0, 123.4, 119.2, 118.0, 79.8, 52.0, 44.0, 43.2, 37.2, 36.3, 36.2, 31.8, 31.6, 31.5, 31.4, 27.0, 26.8, 21.0. Anal. Calcd (\%) for $\mathrm{C}_{32} \mathrm{H}_{31} \mathrm{NO}_{6}$ (525.59): C, 73.13; H, 5.94; N, 2.66. Found: $\mathrm{C}$, $72.81 ; \mathrm{H}, 5.97 ; \mathrm{N}, 2.70$.

X-ray Data for $6 \mathrm{i}$

$\mathrm{C}_{32} \mathrm{H}_{31} \mathrm{~N}_{1} \mathrm{O}_{6}, M=525.58 \mathrm{~g} \cdot \mathrm{mol}^{-1}$, orthorhombic system, space group P212121, $a=10.0889$ (19), $b=11.9344(19), c=22.490$ (3) $\AA, V=2707.9(8) \AA^{3}, Z=4, D_{\text {calcd }}=1.289 \mathrm{~g} \mathrm{~cm}^{-3}, \mu(\mathrm{Mo} \mathrm{K \alpha})=0.089$ $\mathrm{mm}^{-1}$, crystal dimension of $0.50 \times 0.30 \times 0.25 \mathrm{~mm}$. The structure was solved by using SHELXS. The structure refinement and data reduction was carried out with SHELXL of the X-Step32 suite of programs. ${ }^{18}$ Crystallographic data for $\mathbf{6 i}$ have been deposited with the Cambridge Crystallographic Data Centre. Copies of the data can be obtained, free of charge, on application to The Director, CCDC 1019444, Union Road, Cambridge CB2 1EZ, UK. Fax: +44(1223)336033 or e-mail: deposit@ccdc.cam.ac.uk.

rac-Dimethyl \{1-(6-methyl-4-oxo-4H-chromen-3-yl)-2-oxo2-[(1,1,3,3-tetramethylbutyl)amino]ethyl\}malonate (5a) White powder; $\mathrm{mp} 198-201{ }^{\circ} \mathrm{C}$ (dec.). IR $(\mathrm{KBr}): \mathrm{v}_{\max }=3330$ $(\mathrm{NH}), 1730,1681,1649(\mathrm{C}=\mathrm{O}), 1621(\mathrm{C}=\mathrm{C}) \mathrm{cm}^{-1} .{ }^{1} \mathrm{H}$ NMR $(300.1$ $\left.\mathrm{MHz}, \mathrm{CDCl}_{3}\right): \delta=0.83\left(9 \mathrm{H}, \mathrm{s}, \mathrm{CMe}_{3}\right), 1.29\left(6 \mathrm{H}, \mathrm{br} \mathrm{s}, \mathrm{CMe}_{2}\right), 1.49$ and $1.73\left(2 \mathrm{H}, \mathrm{AB}-q\right.$ system, $\left.{ }^{2} J_{\mathrm{HH}}=14.8 \mathrm{~Hz}, \mathrm{CH}_{2}\right), 2.43(3 \mathrm{H}$, 
s, $\left.\mathrm{CH}_{3}\right), 3.55$ and $3.74\left(6 \mathrm{H}, 2 \mathrm{~s}, 2 \mathrm{OCH}_{3}\right), 4.25\left(1 \mathrm{H}, \mathrm{d},{ }^{3} J_{\mathrm{HH}}=12.4\right.$ $\mathrm{Hz}, \mathrm{CH}) 4.58\left(1 \mathrm{H}, \mathrm{d},{ }^{3} J_{\mathrm{HH}}=12.4 \mathrm{~Hz}, \mathrm{CH}\right), 6.40(1 \mathrm{H}, \mathrm{s}, \mathrm{NH}), 7.34(1$ $\left.\mathrm{H}, \mathrm{d},{ }^{3} \mathrm{~J}_{\mathrm{HH}}=8.8 \mathrm{~Hz}, \mathrm{CH}_{3} \mathrm{C}=\mathrm{CHCH}\right), 7.48\left(1 \mathrm{H}, \mathrm{dd},{ }^{3} J_{\mathrm{HH}}=8.8 \mathrm{~Hz},{ }^{3} J_{\mathrm{HH}}\right.$ $\left.=1.6 \mathrm{~Hz}, \mathrm{CH}_{3} \mathrm{C}=\mathrm{CHCH}\right), 7.97(1 \mathrm{H}, \mathrm{s}, \mathrm{C}=\mathrm{CHO}), 7.98(1 \mathrm{H}, \mathrm{s}$, $\left.\mathrm{CH}_{3} \mathrm{C}=\mathrm{CHC}\right) .{ }^{13} \mathrm{C}$ NMR $\left(75.5 \mathrm{MHz}, \mathrm{CDCl}_{3}\right): \delta=177.0,168.6,167.9$, $167.8,154.3,153.6,135.5,135.4,125.2,123.0,119.6,118.0$,
55.2, 52.9, 52.9, 52.0, 51.4, 41.4, 31.4, 31.2, 29.1, 28.7, 20.9. Anal. Calcd (\%) for $\mathrm{C}_{25} \mathrm{H}_{33} \mathrm{NO}_{7}$ (459.53): C, 65.34; $\mathrm{H}, 7.24 ; \mathrm{N}, 3.05$. Found: C, 65.50; H, 7.24; N, 3.08 .

(16) Teimouri, M. B. Tetrahedron 2011, 67, 1837.

(17) Sato, M.; Ban, H.; Kaneko, C. Tetrahedron Lett. 1997, 38, 6689.

(18) X-STEP32 Version 1.07b, X-ray Structure Evaluation Package; Stoe \& Cie: Darmstadt, 2000. 